\title{
Retraction
}

\section{Decrease in the AP-2 DNA-Binding Activity and in the Protein Expression of AP-2 a and AP-2 b in Frontal Cortex of Rats Treated with Lithium for 6 Weeks}

Jagadeesh S Rao, Stanley I Rapoport and Francesca Bosetti

Neuropsychopharmacology (2018) 43, 456; doi:I0.I038/npp.2017.237

Retraction to: Neuropsychopharmacology (2005) 30, 2006-2013; doi:10.1038/sj.npp.1300740; published online 13 April 2005

This article has been retracted by the editor because an investigation by the National Institutes of Health concluded that the data represented by Figures 1c, $4 \mathrm{a}$ and $\mathrm{b}$ were falsified. The authors SIR and FB agree with this retraction. The author JSR could not be reached for comment. 